\title{
日本における地域内旅客交通 $\mathrm{CO}_{2}$ 大幅削減の ための乗合輸送機関導入必要量の算定
}

\author{
伊藤 圭 $^{1} \cdot$ 加藤 博和 $^{2}$ - 柴原 尚希 3 \\ 1学生会員 名古屋大学大学院環境学研究科（†464-8603 名古屋市千種区不老町C1-2(651)） \\ E-mail: k.ito@urban.env.nagoya-u.ac.jp \\ 2 正会員 名古屋大学准教授 大学院環境学研究科（干464-8603 名古屋市千種区不老町C1-2(651)） \\ E-mail: kato@genv.nagoya-u.ac.jp \\ 3 正会員 名古屋大学助教 大学院環境学研究科（广464-8603 名古屋市千種区不老町C1-2(651)） \\ E-mail: nshiba@urban.env.nagoya-u.ac.jp
}

\begin{abstract}
2050年における日本の地域内旅客交通起源 $\mathrm{CO}_{2}$ 排出量を 2000 年比で $80 \%$ 削減するという目標を設定し, その達成のために必要となる交通施策の実施量を地域別に求める. まず，2000年の人口あたり排出量を推 計し, この值の $20 \%$ を各地域交通圈に割り振り，2050年における目標值とする。一方，2050年における排 出量を予測し, 目標達成のため必要となる削減量を把握する. 交通施策として幹線区間における大量輸送 機関の導入を想定し, 路線建設と運行を考慮した $\mathrm{LC}-\mathrm{CO}_{2}$ を最小とする輸送機関とその導入延長を算出す る. 以上の手法により，2050年における $\mathrm{CO}_{2}$ 削減目標の達成のため, 各地域交通圈において必要となる乗 合輸送機関導入必要量や, 都市域面積・人口密度によるその変化について示される.
\end{abstract}

Key Words : backcasting, trunk line, life cycle assessment, low carbon transport system

\section{1. はじめに}

温室効果物質排出増加に起因する気候変動が生態系に 及ぼす不可逆な悪影響を回避するには，2050年における $\mathrm{CO}_{2}$ 排出量を1990年比で半減する必要があるという見通 しをIPCCは公表している1).今後の発展途上国での経済 成長を阻害せずにこれを達成するためには，既に排出量 の多い先進国で半減をはるかに上回る削減が求められる.

日本でも，政権交代を経て環境省がCO 年 $25 \%$ 減, 2050年80\%減(いずれも1990年比)を目標として, それを実現するための施策の検討を進めており ${ }^{2}, \mathrm{CO}_{2}$ の長期的大幅削減を実現する低炭素型社会づくりが重要 な政策課題となっている.

地域内旅客交通は，貨物輸送も含めた運輸部門 $\mathrm{CO}_{2}$ 排 出全体の約4割を占める，その削減には，輸送人 $\mathrm{km}$ あた りの $\mathrm{CO}_{2}$ 排出量(排出原単位)が大きい自家用乗用車の利 用を削減することが不可欠である，そのために最も大き な効果が見込める施策は，大量輸送によって排出原単位 を低減しうる鉄軌道・バス等の乗合輸送機関を，地域内 交通の幹線となる区間に整備していくことである.

具体的な低炭素化施策を検討寸るためには， $\mathrm{CO}_{2}$ 排出 量の将来予測と, 施策の $\mathrm{CO}_{2}$ 排出量削減効果の把握が必
要である. 旅客交通起源 $\mathrm{CO}_{2}$ 排出量のうち大部分を占め る自動車走行起源 $\mathrm{CO}_{2}$ 排出量の推計については, 自動車 単体からの排出量をモデル化した研究が存在する. 例え ば大口ら ${ }^{3)}$ ，大城ら ${ }^{4}$ は平均旅行速度を交通状況を表寸変 数としてモデル化を行っている.

旅客交通起源 $\mathrm{CO}_{2}$ 排出量を地域ごとに推計した研究と して, 平野ら゙は全国PT調査の結果を用いて自動車の $\mathrm{CO}_{2}$ 排出量を推計し, 都市規模別に経年変化を分析して いる. 町村部も含めた推計として, 松橋らすは道路交通 センサス自動車起終点調査のデータを用い，自家用車走 行起源 $\mathrm{CO}_{2}$ 排出量を市区町村別に推計している. 加えて, その推計・集計方法の違いによって推計值に大きな差が 生じることを示している. 工藤ら》はこの研究を発展さ せ，旅客鉄道走行起源のCO 2 排出量についても市区町村 ごとに集計する手法を提案している.

政策分析を意識した推計手法として，小島ら ${ }^{8}$ / は四段 階推定法の一部を統合した均衡モデルを構築し, 仙台都 市圈を対象として夜間人口，従業人口分布の違いによる 交通施策の効果を分析している. 山崎ら ${ }^{9}$ は都市構造, 特に交通インフラ整備が旅客交通に与えてきた影響に注 目し，交通インフラ整備によるトリップ長・ $\mathrm{CO}_{2}$ 排出量 の変化を推計している. 
一方，中村ら ${ }^{10}$ は，市区町村規模別に運輸部門 $\mathrm{CO}_{2}$ 排 出量を推計し, 削減量の目標值を達成するための施策量 をバックキャスティングアプローチによって推計してい る. その結果, 単一施策による目標達成は困難であり, 複数施策の組み合わせが必要であることを示している. 栗山ら ${ }^{11}$ は，日本におけるEST施策の実施を阻害する要 因を分析し，EST実現に向けた施策は互いに密接な関連 を持っていることから, 総合的なパッケージとして施策 を実施する必要性を示している，しかし，これらの研究

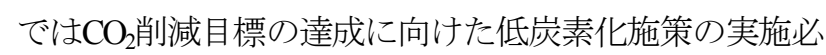
要量を示すには至っていない.

以上を踏まえ本研究では, 日本の地域内旅客交通を対 象として, 地域ごとにCO 2 削減目標量を推計し, その達 成に必要となる施策実施量を求める手法を開発する. 削 減目標值は2050年における $\mathrm{CO}_{2}$ 排出量を2000年比で $80 \%$ 削減すると設定し，施策には乗合輸送機関の導入を取り 上げる.

なお，乗合輸送機関を新たに整備する場合，インフラ 建設等による $\mathrm{CO}_{2}$ 排出が伴う。これを加味した分析を行 うために，ライフサイクルアセスメント(Life Cycle Assessment; LCA)を適用する.

\section{2. 分析の考え方}

\section{(1) 検討の手順}

2050年における旅客交通起源 $\mathrm{CO}_{2}$ 排出量の推計にあた って, 車両技術・燃費の改善をシナリオとして設定し, 外生的に与える. その上で, 削減目標を達成するため, 各地域でどの程度, 乗合輸送機関を導入する必要がある かを推計する。

乗合輸送機関は一般に，輸送人 $\mathrm{km}$ あたり走行起源 $\mathrm{CO}_{2}$ 排出量が乗用車に比べて小さい. ただし，これは大量輸 送による効果であり, 輸送量が少なければ乗用車の $\mathrm{CO}_{2}$ 排出量を上回る場合もありうる。つまり，乗合輸送機関 導入が $\mathrm{CO}_{2}$ 削減効果を発揮するには高い輸送密度が必要 となる，この条件を満たすためには，沿線の人口密度が 高く, 総人口も多いことが求められる.

郷ら ${ }^{12}$ は，国内の既存鉄道の実績值から，地域特性を 示寸指標と輸送密度の関係を分析し, 地域のDID 人口密 度との関係が他のどの指標よりも強いことを明らかにし ている. 加えて, 乗合輸送機関の新規整備による $\mathrm{CO}_{2}$ 削 減効果をマクロ分析のアプローチで算出する手法を開発 し，採算性・輸送力を考慮に入れた上で， $\mathrm{CO}_{2}$ 排出が最 小となる輸送機関を選定している．本研究ではこの方法 を発展させて適用する. 以上の分析枠組を図-1に示す.

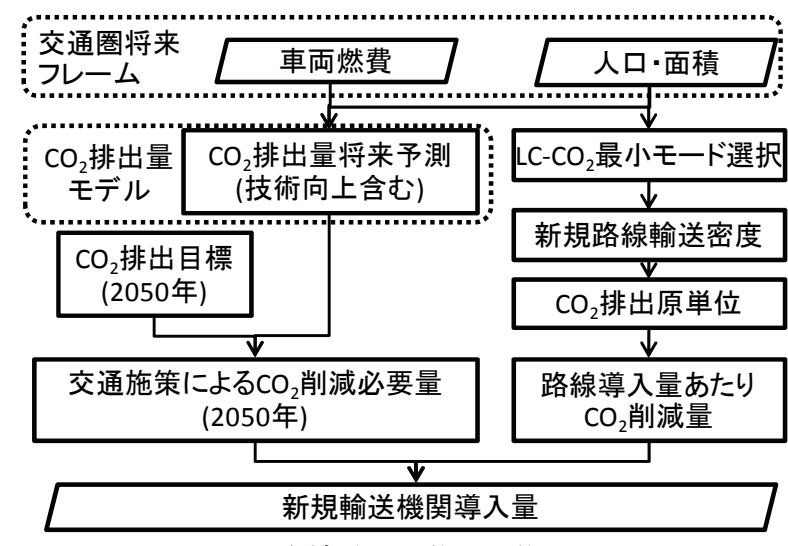

図-1 乗合輸送機関導入量導出フロー

表-1 地域交通圈の設定基準

\begin{tabular}{|c|c|}
\hline $\begin{array}{c}\text { 核都市 } \\
\text { (C) }\end{array}$ & $\begin{array}{l}\text { a) 人口 } 10 \text { 万人以上かつ昼間人口/夜間人口 } \geqq 1.00 \\
\text { の市区町村 } \\
\text { b) } 20 \mathrm{~km} \text { 以内にある市区町村はまとめる }\end{array}$ \\
\hline $\begin{array}{c}\text { 周辺都市 } \\
\text { (S) }\end{array}$ & $\begin{array}{l}\text { a) 核都市への通勤・通学者が } 500 \text { 人以上の市町 } \\
\text { 村 } \\
\text { b) 核都市への(通勤・通学者) / (在住通勤・通学 } \\
\text { 者) }>0.05 \text { の市町村 } \\
\text { c) } 2 \text { 以上の都市圈に含まれる市町村は, 核都市 } \\
\text { への通勤・通学者のより多い都市圈に含む }\end{array}$ \\
\hline $\begin{array}{c}\text { 非都市 } \\
\text { (R) }\end{array}$ & 核都市，周辺都市に含まれない地域 \\
\hline
\end{tabular}

\section{（2）分析の空間単位（地域交通圏）の定義}

日常的な交通行動は, 市区町村単位を越えた範囲で行 われる. 本研究では, 通勤・通学による人の動きに着目 したKawashima et al. ${ }^{13}$ にによる機能的都市地域の定義に基づ いて全国市区町村を分割する. 本研究ではこれを「地域 交通圈」と呼び，分析単位とする．地域交通圈は，表-1 によって定義される核都市(C)とそれに属する周辺都市 (S)によって構成され, 全国に85地域(113核都市)が設定さ れる. 一方，核都市にも周辺都市にも分類されない非都 市(R)は地域交通圈に属さない. 非都市は乗合輸送機関 の整備効果が得られにくいため, 本研究では導入地域と して扱わない。

\section{3. 旅客交通起源 $\mathrm{CO}_{2}$ 削減必要量の算出}

\section{(1) 2000 年の $\mathrm{CO}_{2}$ 排出量の把握}

2050年における $\mathrm{CO}_{2}$ 排出目標值を決定するため, まず, 2000年における $\mathrm{CO}_{2}$ 排出量を推計する. 地域内旅客交通 の輸送機関として自家用乗用車，バス，鉄道を対象とす る. 推計および将来予測は市区町村(2000年現在)単位で 行い，地域交通圈で集計する．以下に輸送機関別の推計 方法を述べる. 


\section{a) 自家用乗用車・バス}

自家用乗用車は普通乗用車と軽乗用車から構成される。 $\mathrm{CO}_{2}$ 排出量は, 車種別の走行距離に $\mathrm{CO}_{2}$ 排出原単位を乗 じて導出される(式(1)).

$$
E=\left(\sum_{k} L_{k}^{\text {weekday }}+\sum_{k} L_{k}^{\text {holiday }}\right) \cdot e_{k}
$$

ここで, $E: \mathrm{CO}_{2}$ 排出量, $L_{k}$ : 車両走行距離, $e_{k}: \mathrm{CO}_{2}$ 排 出原単位, $k$ : 車種(普通乗用車・軽乗用車・バス)

本研究では，自家用乗用車走行距離を全国的に得る必 要があるため, 道路交通センサス自動車起終点調査の結 果を用いて，走行距離を車両登録地に集計する．ただし， 同調査が2000年には行われていないため，直近の1999年 に行われた調査の結果を用いて推計する.

自家用乗用車・バスの $\mathrm{CO}_{2}$ 排出原単位は，平均旅行速 度をパラメータとする大城ら ${ }^{4} に よ る$ 燃料消費率推計式 を用いて算出する.

乗用車の $\mathrm{CO}_{2}$ 排出原単位は地域の道路交通状況によっ て変化する. 特に, 都市部では道路混雑による加速走行 の増加により，值が大きくなると考えられる，そこで， DIDが存在する市区町村については, 乗用車平均旅行速 度をDID人口密度を説明変数とする回帰モデルによって 推計する，道路交通センサス一般交通量調査より，往復 2車線舗装道路について混雑時平均旅行速度(平日)を抽 出し，調査区間のうちDIDに含まれる距離が50\%以上と なるデータ $(n=617)$ をDID内における乗用車の平均旅行速 度と考える. 本データは朝のラッシュ時間帯（午前7時 から午前9時) または，タ方のラッシュ時間帯（午後5時 から午後7時）に計測された旅行速度であり，終日平均 の旅行速度はこれ以上の值となるが，データ制約より便 宜的にこの值を用いる.

図-2にDID人口密度 $1,000\left[\right.$ 人 $\left./ \mathrm{km}^{2}\right]$ ごとに平均值をとり， 平均旅行速度と $\mathrm{DID}$ 人口密度との関係を示寸． DID 人口 密度が増加するにつれて，平均旅行速度が低下寸ること が分かる.この関係を式(7)に示すコブ・ダグラス型関 数を用いたモデルを構築する.

$$
v=\exp \left(\delta_{0}\right) \cdot D_{d}^{\delta_{1}}
$$

ここで， $v$ : 乗用車平均旅行速度 $[\mathrm{km} / \mathrm{h}], D_{d}: \mathrm{DID}$ 人口密 度 $\left[\right.$ 人 $\left./ \mathrm{km}^{2}\right], \delta_{0}, \delta_{1}$ : パラメータ

表-2に，式(2)のパラメータ推定結果を示す．DIDが存 在しない市区町村の平均旅行速度は，式(7)に人口密度 $4000\left[人 \mathrm{~km}^{2}\right]$ を代入した值を用いる.

\section{b) 鉄道}

平成12年度(2000年度)鉄道統計年報を用いて推計する。 まず，事業者別に集計された電力・燃料等の使用量を輸 送人 $\mathrm{km}$ で路線ごとに按分する．按分した電力量・燃料 消費量に使用エネルギー別 $\mathrm{CO}_{2}$ 排出原単位 ${ }^{14}$ を乗じる. 路線ごとに推計された $\mathrm{CO}_{2}$ 排出量を，さらに，駅数に応

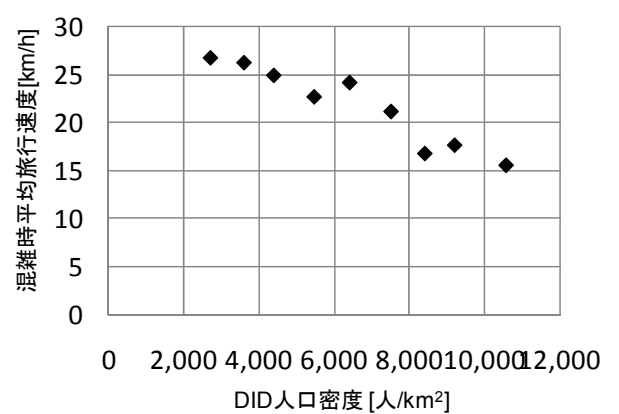

図-2 乗用車平均旅行速度とDID人口密度との関係

表-2 乗用車平均旅行速度モデル(式(7))の パラメータ推計結果

\begin{tabular}{c|r|r|r|r}
\hline 変数名 & $\begin{array}{c}\text { パラメ } \\
\text { ータ }\end{array}$ & $\mathrm{t}$ 值 & $\begin{array}{r}\text { 自由度調 } \\
\text { 整済 } \mathrm{R}^{2} \text { 值 }\end{array}$ & $\begin{array}{r}\text { サンプ } \\
\text { ル数 }\end{array}$ \\
\hline 定数項 & 65.7 & 113 & & \\
\hline $\begin{array}{c}\text { 可住地人口密度 } \\
{\left[\text { [人 } \mathrm{km}^{2}\right]}\end{array}$ & -0.405 & -5.68 & 0.822 & 9 \\
\hline
\end{tabular}

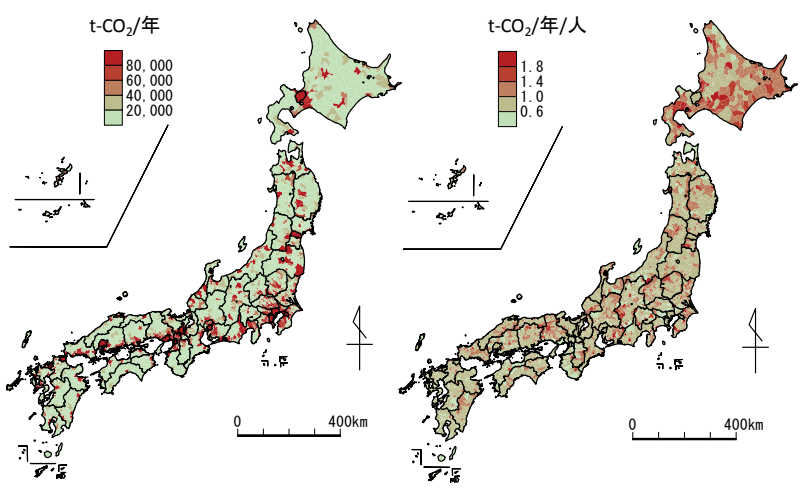

(a) 総排出量

(b)人口あたり排出量

図-3 市区町村別旅客交通起源 $\mathrm{CO}_{2}$ 排出量(2000年)

じて市区町村へ按分する.

a)およびb)で推計した $\mathrm{CO}_{2}$ 排出量の合計值を2000年に おける旅客交通起源 $\mathrm{CO}_{2}$ 排出量とする。 その全国市区町 村ごとの推計結果を図-3に示す.

市区町村別総排出量は，東京・大阪などの大都市部で 当然大きくなるが，人口1人あたりにすると，地方部で の排出量が大きい，その主な要因は，大都市では公共交 通に，地方部では自家用乗用車に依存した交通形態であ ることによる，人 $\mathrm{km} あ た り \mathrm{CO}_{2}$ 排出原単位の差異である.

\section{(2) 将来(2050年)の排出量予測モデルの構築 a) 自家用乗用車}

保有台数と1台あたり走行距離のそれぞれについてモ デルを構築し，2050年における $\mathrm{CO}_{2}$ 排出量の予測に適用 する. 
表-3 自家用乗用車保有台数推計モデル $<$ 核都市 $>($ 式(3))のパラメータ推計結果

\begin{tabular}{|c|c|c|c|c|}
\hline 変数名 & パラメータ & $t$ 值 & 自由度調整済 $R^{2}$ 值 & サンプル数 \\
\hline 定数項 & 1.71 & 6.97 & \multirow{5}{*}{0.987} & \multirow{5}{*}{113} \\
\hline $\mathrm{DID}$ 人口密度[人 $\left.\mathrm{km}^{2}\right]$ & -0.230 & -6.67 & & \\
\hline 生産可能年齢人口[人] & 1.01 & 92.2 & & \\
\hline 1人あたり道路延長 $[\mathrm{km} /$ 人] & 0.0805 & 4.10 & & \\
\hline 鉄道駅ダミー & 0.0605 & 2.19 & & \\
\hline
\end{tabular}

表-4 自家用乗用車保有台数推計モデル $<$ 周辺都市 $>$ 補正関数(式(5))のパラメータ推計結果

\begin{tabular}{c|r|r|r|r}
\hline 変数名 & \multicolumn{1}{|c|}{ パラメータ } & $t$ 值 & 自由度調整済 $R^{2}$ 值 & サンプル数 \\
\hline 定数項 & -3.87 & -14.4 & \\
可住地人口密度 $\left[\mathrm{Nkm}^{2}\right]$ & 0.0722 & 10.3 & \multirow{2}{*}{0.586} & 1367 \\
\hline 1 人あたり道路延長比率 & 0.144 & 18.9 & \\
\hline 生産可能年齢人口割合 & 0.807 & 11.1 & \\
\hline
\end{tabular}

表-5 自家用乗用車走行距離推計モデル(式(6))のパラメータ推計結果

\begin{tabular}{|c|c|c|c|c|}
\hline 変数名 & パラメータ & $t$ 值 & 自由度調整済 $R^{2}$ 值 & サンプル数 \\
\hline 定数項 & 10.6 & 33.0 & \multirow{3}{*}{0.622} & \multirow{3}{*}{47} \\
\hline 可住地人口密度 $\left[\mathrm{km}^{2}\right]$ & -0.198 & -6.03 & & \\
\hline 駅数総面積[駅 $\left./ \mathrm{km}^{2}\right]$ & 0.0680 & 2.33 & & \\
\hline
\end{tabular}

\section{<保有台数モデル $>$}

保有台数モデルは，表-1の分類ごとに市区町村単位で 構築する. 乗用車保有率を算出することも考えたが，決 定係数の高さから, 保有台数を直接求める形のモデルを 選択している.

・榜都市(C)

式(3)のコブ・ダグラス型関数で表現する.

$y_{C_{i}}=\exp \left(\alpha_{0}\right) \cdot D_{d C_{i}}^{\alpha_{1}} \cdot A_{C_{i}}^{\alpha_{2}} \cdot R_{C_{i}}^{\alpha_{3}} \cdot \exp \left(\alpha_{4} \cdot d_{s}\right)$

ここで， $i$ : 地域交通圈， $C$ : 核都市， $y$ : 自家用乗用車 保有台数 $\left[\right.$ 台], $D_{d}: \mathrm{DID}$ 人口密度 $\left[\right.$ 人 $\left./ \mathrm{km}^{2}\right], A$ : 生産可能 年齢人口[人], $R: 1$ 人あたり道路延長 $\left[\mathrm{km} /\right.$ 人], $d_{s}$ : 鉄道 駅ダミー $\left(d_{s}=0,1\right), \alpha_{0}, \alpha_{1}, \alpha_{2}, \alpha_{3}, \alpha_{4}:$ パラメータ

表-3に，2000年の市区町村データを用いて推定した， 式(3)のパラメータを示す. 推定の結果, 乗用車保有台 数は人口ではなく生産年齢人口に大きく依存しているこ とが分かる，そのパラメータはほぼ1であり，両辺を生 産年齢人口で除することによって「生産年齢人口あたり 保有台数」のモデルになっているという解釈が可能であ る.

\section{- 周辺都市 $(\mathrm{S})$}

自身が所属する核都市から影響を受けると考え，その 核都市の自家用乗用車保有台数に, 修正関数 $g($ 式(5))を 乗じて求めるものとする(式(4)).

$$
\begin{aligned}
& y_{s_{i}}=y_{c_{i}} \cdot g \\
& g=\exp \left(\beta_{0}\right) \cdot D_{r}^{\beta_{1}} \cdot\left(\frac{R}{R_{C_{i}}}\right)^{\beta_{2}} \cdot A^{\beta_{3}}
\end{aligned}
$$

ここで, $g$ : 補正関数, $D_{r}$ : 可住地人口密度 $\left[人 / \mathrm{km}^{2}\right]$,
$R: 1$ 人あたり道路延長 $[\mathrm{km} /$ 人 $], R_{c i}$ : 所属核都市 1 人あた り道路延長 $[\mathrm{km} /$ 人 $], \beta_{0,}, \beta_{1}, \beta_{2}, \beta_{3}$ : パラメータ

表-4に，2000年の市区町村データを用いて推定した， 式(5)のパラメータを示す.

・非都市(R)

既に1人あたり自家用乗用車保有台数は飽和状態にな っていると考え，現状(2000年)のまま一定とする.

<1台あたり走行距離モデル >

コブ・ダグラス型関数を用いたモデルを構築する(式 (6)).

$$
T=\gamma_{0} \cdot D_{r}^{\gamma_{1}} \cdot S_{t}^{\gamma_{2}}
$$

ここで， $T: 1$ 台あたり走行距離 $\left[\mathrm{km} /\right.$ 台], $S_{t}$ : 可住地面積 あたり駅数 $\left[\mathrm{fD}_{2} / \mathrm{km}^{2}\right], \gamma_{0}, \gamma_{1}, \gamma_{2}$ : パラメータ

1台あたり走行距離は市区町村別デ現況一タでは明確 な傾向が得られなかったため，ここでは傾向が見いださ れた都道府県別に推定することとした．表-5にパラメー タ推計結果を示す.

\section{b) バス・鉄道}

1台あたり乗車人数の変化が小さい自家用乗用車とは 異なり，運行量(車両 $\mathrm{km}$ ) と輸送需要 $(人 \mathrm{~km})$ とは必ずしも 比例関係でない. また, 本研究ではその整備量が後に分 析対象となることから，ここでは運行量のモデル化は行 わず，2000年時の運行量が維持されるものとする.

\section{(3) 車両・燃料技術シナリオ}

車両・然料技術について，a)技術固定シナリオとb)技 術向上シナリオを考え, 各輸送機関の排出原単位を設定 する. 
表-6 車両・燃料技術の b)技術向上シナリオにおけるエネルギー効率の設定

\begin{tabular}{c|c|c|c|c}
\hline & エネルギー/車両 & 2000 年 & 2050 年 & 改善率 \\
\hline \multirow{3}{*}{ WtT 効率 } & ガソリン・軽油 & 0.88 & 0.88 & 1.00 \\
\cline { 2 - 5 } & 電力 & 現状值 & 現状值 $\times 2$ & 2.00 \\
\hline \multirow{3}{*}{$\mathrm{T} t W$ 効率 } & ガソリン車・ハイブリッド車 & 0.16 & 0.26 & 1.60 \\
\cline { 2 - 5 } & 電気自動車 & 0.70 & 0.95 & 1.36 \\
\cline { 2 - 5 } & 鉄道(電化) & 0.84 & 0.97 & 1.15 \\
\hline
\end{tabular}

表-7 旅客交通起源 $\mathrm{CO}_{2}$ 排出量推計值

\begin{tabular}{c|c|c|c}
\hline & 2000 年 & 2050 年 $\mathrm{a})$ 固定 & 2050 年 $\mathrm{b})$ 向上 \\
\hline 自家用乗用車総走行距離 $[\mathrm{km} /$ 台 $]$ & $3.79 \times 10^{11}$ & \multicolumn{2}{|c}{$2.58 \times 10^{11}$} \\
\hline 1 台あたり自家用乗用車走行距離 $[\mathrm{km} /$ 台 $]$ & 7,550 & \multicolumn{2}{|c}{8,011} \\
\hline 旅客交通起源 $\mathrm{CO}_{2}$ 排出量 $\left[\mathrm{Mt}_{-} \mathrm{CO}_{2}\right.$ 年 $]$ & $9.68 \times 10^{7}$ & $7.15 \times 10^{7}$ (26.1\%減) & $3.28 \times 10^{7}(66.1 \%$ 減) \\
\hline 1 人あたり旅客交通起源 $\mathrm{CO}_{2}$ 排出量 $\left[\mathrm{t}-\mathrm{CO}_{2} /\right.$ 人・年 $]$ & 0.763 & 0.720 (5.61\%減) & 0.329 (56.7\%減) \\
\hline
\end{tabular}

\section{a) 技術固定シナリオ}

2050年の燃費・車両構成を2000年から不変とする.

\section{b) 技術向上シナリオ}

低環境負荷車両は「超長期エネルギー技術ロードマッ プ報告書」 ${ }^{15}$ を参考に，ハイブリッド車と電気自動車の 2 種類が普及すると仮定し，WtW(Well to Wheel)効率を設 定する. WtT(Well to Tank)効率の改善は同時に, 電力を 使用寸る鉄道の走行起源 $\mathrm{CO}_{2}$ 排出量改善につながる. 車 両製造段階とインフラ整備段階からの $\mathrm{CO}_{2}$ 排出量は 2000 年から不変とする. 既報 ${ }^{10-18)}$ から 2000 年と 2050 年 における WtT 効率，TtW(Tank to Wheel)効率を表-6のよう に設定する. この電力効率の設定について, 超長期エネ ルギー技術ロードマップ報告書の中には，排出原単位が 3 分の 1 まで減少するとの試算もあり, 本研究で採用し たのは比較的低位な設定である.

\section{(4) 2050 年 $\mathrm{CO}_{2}$ 排出量推計}

人口は, 対象市区町村の 5 歳別将来人口をコーホート 要因法により推計する. 本研究では, 2035年までの各年 における自治体人口については，人口問題研究所(2004) が算出した值を用いている．2040年以降2055年までの人 口については, 2030年から2035年までの, 出生率, 生存 率, 純移動率の平均值を延長する形で推計を行う.

可住地面積を, 人口増加の場合は人口に比例して増加 させ，人口が減少する場合は変化しないものとする．ま た, 道路延長は可住地面積に比例して変化させることと する. 以上の仮定に基づく $\mathrm{CO}_{2}$ 排出量推計結果を表-7に 示寸.

\section{a) 技術固定シナリオ}

総人口減少( $21.8 \%$ 減)と人口構成の変化に伴って, 自家 用乗用車保有台数が減少寸る(31.9\%減)が，同時に人口密 度が低下寸るため1台あたり自家用乗用車走行量は増加 する. $\mathrm{CO}_{2}$ 排出量は2000年と比較して全国で26\%減少し, 1人あたり排出量で比較した場合は $5 \%$ の減少となる.

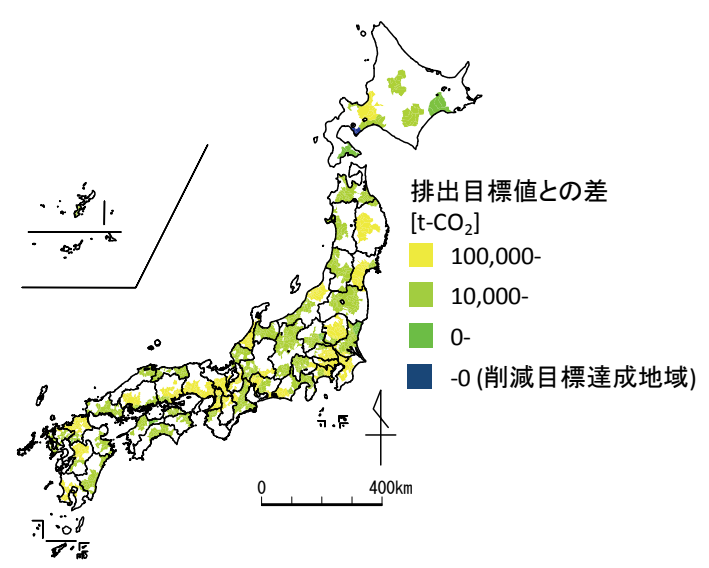

図-4 $\mathrm{CO}_{2}$ 削減目標未達成地域と必要削減量 (技術向上シナリオ，2050年)

b) 技術向上シナリオ

総排出量は2000年と比較して $66 \%$ の減少，人口 1 人あ たり排出量でも57\%の減少となっている．しかし，2000 年比 $80 \%$ 削減という目標には至らず，交通施策が必要で あることが分かる。

図-4に2050年における $\mathrm{CO}_{2}$ 排出量推計值を地域交通圈 単位で集計し，排出目標值との差として示す．排出目標 を達成した交通圈は1地域(室蘭)のみである.

\section{4. 乗合輸送機関の選定と導入規模の推計}

\section{（1）乗合輸送機関選定}

乗合輸送機関導入の検討においては，導入自体が新た な $\mathrm{CO}_{2}$ 排出を伴うことに注意が必要である. 専用のイン フラを伴いながら輸送密度が低い輸送機関の場合，走行 起源 $\mathrm{CO}_{2}$ に比べて建設起源の $\mathrm{CO}_{2}$ 排出量が相対的に大き くなる，そのことを考慮するために，インフラ建設，車 両製造, および供用の各段階からの $\mathrm{CO}_{2}$ 排出量の合計值 
（これをSystem Life Cycle $\mathrm{CO}_{2}<\mathrm{SyLC}-\mathrm{CO}_{2}>$ と呼ぶ）を算出 する.

先行研究 ${ }^{19} に$ において, 中量輸送機関の輸送人 kmあたり SyLC-CO $\mathrm{C}_{2}$ と輸送密度の関係を示している. 輸送密度が 増加するにつれて SyLC-CO 2 が最小となる乗合輸送機関 は, BRT, LRT, 鉄道と交代していく.

図-5に，2000年と2050年における各輸送機関の輸送密 度とSyLC-CO 2 の関係を示す。乗合輸送機関は輸送密度 の増加に従い，輸送人 $\mathrm{km}$ に割りあてられる運行以外の $\mathrm{CO}_{2}$ が小さくなるため, 輸送人kmあたり SyLC-CO $\mathrm{CH}_{2}$ は減少 していく.インフラの建設に伴う単位路線延長あたり $\mathrm{CO}_{2}$ 排出量はBRTが最も小さいため, 輸送密度が小さい 場合では乗合輸送機関の中でBRTがSyLC-CO 2 最小となる。 輸送密度6,000[人/日]付近でBRTとLRTのSyLC-CO 2 が拮抗 する. それ以上の輸送密度では, 車両走行の $\mathrm{CO}_{2}$ 排出量 が小さいLRTが，SyLC-CO 2 最小の輸送機関となる.

ここでは，上記の乗合輸送機関に加えて乗用車の SyLC- $\mathrm{CO}_{2}$ を比較し, 最小となる輸送機関を選択する. 乗合輸送機関の導入による波及的な $\mathrm{CO}_{2}$ 削減効果として, 地域の交通体系を変化させることを考慮に入れる必要が あるが，本研究では，そのメカニズムのモデル化に至っ ていないため，単純に自家用乗用車利用者が乗合輸送機 関に転換すると考える.よって, 自家用乗用車利用の削 減量は乗合輸送機関の輸送密度と路線延長を乗じた值に 一致する.この関係を式(7)に示す.

$$
\Delta L=T_{d} \cdot l
$$

ここで， $\Delta L$ : 転換量 $\left[\right.$ 人 $\mathrm{km} /$ 日], $T_{d}$ : 輸送密度[人/日], $l:$ 路線延長 $[\mathrm{km}]$

郷ら ${ }^{12)}$ の先行研究で, 国内の地下鉄 - 路面電車 AGT・モノレール等の輸送密度，表定速度などの実績值 と地域特性との関係を分析した。 その結果, 輸送密度と 地域交通圈の中心都市のDID人口密度との間に比較的強 い相関が見られることが示されている. 鉄道とLRT・ BRTでそれぞれに得られる輸送密度とDID人口密度との 関係式を図-6に示す。

ガソリン乗用車とハイブリッド乗用車の $\mathrm{CO}_{2}$ 排出原単 位については，大城 $5^{4)}$, Kudoh et $\mathrm{al}^{20}{ }^{20}$ の平均旅行速度を パラメータとする燃料消費率推計式に式(7)の関係を代 入し推計する. 電気乗用車の排出原単位については，加 減速時の $\mathrm{CO}_{2}$ 排出量が小さいため走行環境に関わらず一 定と設定する.

以上の方法により, SyLC- $\mathrm{CO}_{2}$ 最小でかつ導入可能な 輸送機関を選定する。図-5に示した各輸送機関のSyLC$\mathrm{CO}_{2}$ と輸送密度の関係にこの結果を組み込むことで，核 都市のDID人口密度とその地域交通圏に導入する輸送機 関から排出されるSyLC-CO 2 の関係が示される(図-7).

$\mathrm{DID}$ 人口密度から輸送密度を導出する際に, 図一のよ

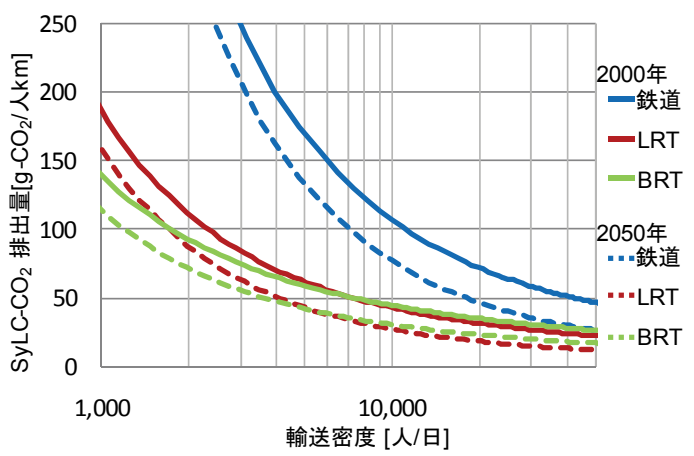

図-5 需要量に伴う各輸送機関 SyLC-CO 2 の変化

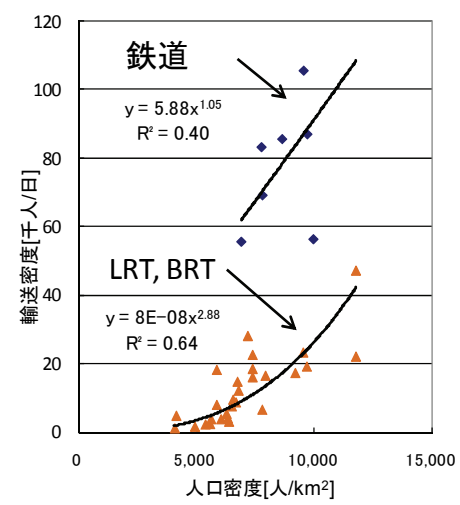

図-6 輸送密度と DID 人口密度との関係

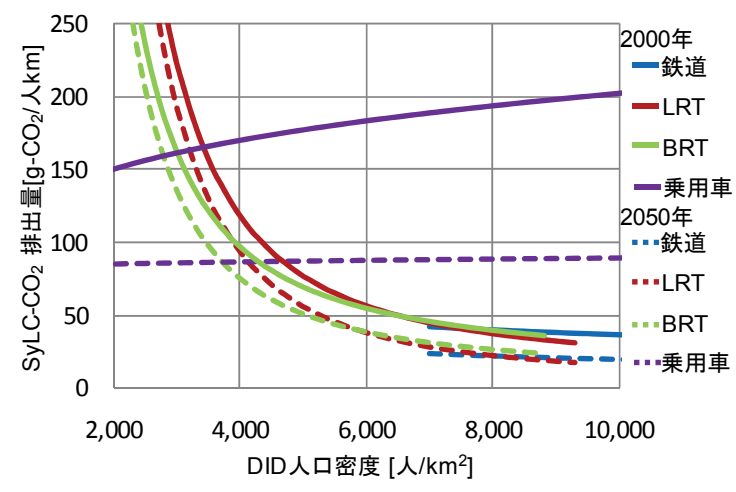

図-7 DID 人口密度と SyLC-CO 2 排出量との関係

うに鉄道と $\mathrm{LRT}$ ・BRT とで異なる関係式を用いており， 同じ人口密度で鉄道が LRT・BRT に比べ輸送密度が大 きいため, 鉄道の LRT・BRT に対する優位性が大幅に 向上する.

2000 年の走行起源 $\mathrm{CO}_{2}$ 排出量原単位において SyLC$\mathrm{CO}_{2}$ を最小とする輸送機関は，人口密度 $3,100\left[\right.$ 人 $\left./ \mathrm{km}^{2}\right]$ 以 下の地域では乗用車, $3,100\left[\right.$ 人 $\left./ \mathrm{km}^{2}\right] \sim 6,400\left[\right.$ 人 $\left./ \mathrm{km}^{2}\right]$ では BRT, $6,400\left[\right.$ 人 $\left./ \mathrm{km}^{2}\right] \sim 7,000\left[\right.$ 人 $\left./ \mathrm{km}^{2}\right]$ では LRT, 7,000[人 $\mathrm{km}^{2}$ ]以上では鉄道・LRT となる. 一方，2050 年に想定 される走行起源 $\mathrm{CO}_{2}$ 排出量原単位の下では, 人口密度 4,200[人 $/ \mathrm{km}^{2}$ ]以下では乗用車, 4,200 [人 $\left./ \mathrm{km}^{2}\right] \sim 5,900$ [人 $/ \mathrm{km}^{2}$ ]では BRT, 5,900 [人 $\left./ \mathrm{km}^{2}\right] 〜 7,000\left[\right.$ 人 $\left./ \mathrm{km}^{2}\right]$ では LRT, $7,000\left[\right.$ 人 $\left./ \mathrm{km}^{2}\right]$ 以上では鉄道・LRT となる.このように, 電気自動車の大量普及に伴う乗用車の走行起源 $\mathrm{CO}_{2}$ 排出 
表-8 各地域交通圏における $\mathrm{SyLC}-\mathrm{CO}_{2}$ 最小輸送機関

\begin{tabular}{|c|c|c|c|}
\hline & & 2000 年 & 2050年 \\
\hline \multicolumn{2}{|l|}{ 地域交通圈内総人口[100万人] } & 111 & 90.2 \\
\hline \multicolumn{2}{|c|}{ 地域交通圈あたり平均人口 $[100$ 万人地域 $]$} & 1.31 & 1.06 \\
\hline \multirow{4}{*}{$\begin{array}{c}\left.\text { SyLC-CO }{ }_{2} \text { 最小輸送機関別各都市数 [都市 }\right] \\
\text { 括弧内は地域交通圈人口 [100 万人] }\end{array}$} & 鉄道 & $6(11.1)$ & $5(42.5)$ \\
\hline & LRT & $9(47.4)$ & $5(1.45)$ \\
\hline & BRT & $97(52.3)$ & $45(29.4)$ \\
\hline & 乗用車 & $1(0.191)$ & $58(16.8)$ \\
\hline
\end{tabular}

量原単位の大幅な改善によって, 輸送密度の小さい領域 において，乗用車が $\mathrm{SyLC}-\mathrm{CO}_{2}$ 最小となる範囲が拡大し ていることが分かる.

以上の結果を用いて，2000年と2050年において日本の 各地域交通圈でSyLC-CO 2 最小となる輸送機関を選定し た結果を表-8に，地域交通圈総人口と併せて示寸，複数 の核都市を持つ地域交通圈では，核都市ごとに輸送機関 が選定される.

2050年には人口密度低下・技術向上によって乗用車が SyLC- $\mathrm{CO}_{2}$ 最小となる地域交通圈が増える。そのような 地域交通圏では，乗合輸送機関の導入が $\mathrm{CO}_{2}$ 削減施策と して機能しない地域である。このような事態を避けるた めには，地域の人口密度を高め乗合輸送機関導入が $\mathrm{CO}_{2}$ 排出量を削減しうる状態を作り出すことが必要である. 具体的には，軌道系輸送機関が導入可能となる4,200[人 $\left.\mathrm{km}^{2}\right]$ 以上の地域をつくり出す必要がある. 具体的な検 討は(3)で行う.

\section{（2）乗合輸送機関の導入量の決定}

自家用乗用車利用者が乗合輸送機関に転換することで 削減される排出量 $\Delta E\left[\mathrm{t}-\mathrm{CO}_{2}\right]$ は，転換量 $\Delta L$ と輸送人 $\mathrm{km}$ あたり $\mathrm{CO}_{2}$ 削減量を乗じた值となる(式(8)).

$$
\Delta E=\left(e_{c a r}-e_{p u b}\right) \cdot \Delta L
$$

ここで， $e_{a r a}$ : 人 $\mathrm{km}$ あたり排出量(自家用乗用車) $\left[\mathrm{t}-\mathrm{CO}_{2} /\right.$ 人 $\mathrm{km}], e_{p u b}$ : 人 $\mathrm{km}$ あたり排出量(乗合輸送機関) $\left[\mathrm{t}-\mathrm{CO}_{2} /\right.$ 人 $\left.\mathrm{km}\right]$ 式(7), 式(8)より, 削減目標を達成するために必要と なる新設路線延長 $l$ は式(9)で算出される.

$$
l=\frac{\Delta E}{T d \cdot\left(e_{c a r}-e_{p u b}\right)}
$$

図-8に，2000年時点でSyLC-CO 2 を最小とする輸送機関 に鉄道・LRTが選定される地域交通圈について，必要路 線延長を推計した結果を示す。この值は，削減すべき $\mathrm{CO}_{2}$ 排出量と人口密度に左右される. 結果より, 大都市 圈において重点的に鉄軌道系の輸送機関を整備する必要 性が示唆される．新規路線は輸送密度の高い状態を維持 する必要があるため, 既存路線網が充実している地域に おいては，沿線への人口誘導策を合わせて実施し，路線

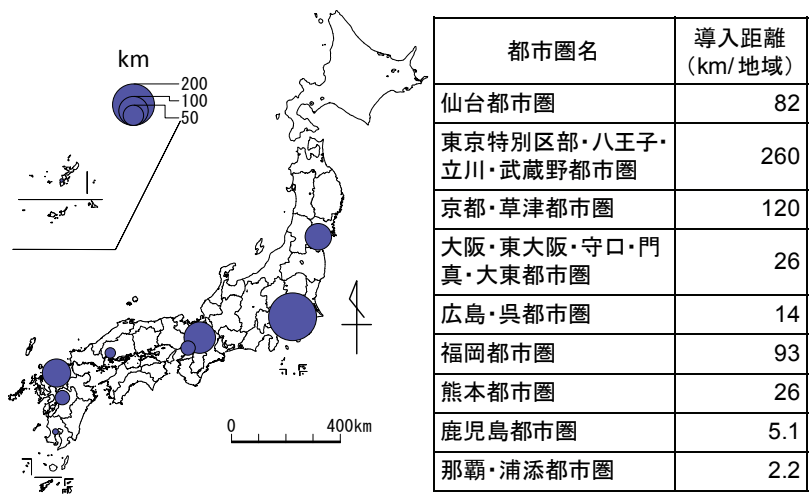

図-8 LRT ・ 鉄道選定交通圏におけるその導入必要延長 (2000年, 可住地面積あたり)

網が貧弱な地方都市では，新たな交通軸として路線を整 備することが必要である.

\section{（3）都市域縮退が乗合輸送機関導入量に与える効果}

そこで，都市域面積を縮小させること（都市域縮退） が輸送機関導入施策へ与える影響について分析する。こ こでは，a）2000年の可住地面積とDID面積を一定とした 場合，b) 2000年の人口密度を維持するように，各交通圈 の可住地面積とDID面積を変化させる場合のシナリオを 用意する，後者は各交通圈の人口減少に合わせて都市域 も縮退する.

3章(4)の設定よりも人口密度が増加することから，乗 合輸送機関の輸送密度は高くなり，輸送人kmあたりに 割り当てられる路線建設・車両製造の $\mathrm{CO}_{2}$ 排出量は低位 で推移する.

設定した面積変化において，SyLC-CO 輸送機関と, 排出目標非達成地域で必要となる導入距離 を地域交通圈人口と併せて表-9に示す。また，図-9に SyLC-CO ${ }_{2}$ 最小輸送機関の選定地域を示す.

都市域縮退によって, 乗用車がSyLC-CO 2 最小となる 地域交通圈が減少する。ただし，そのような地域の多く は，人口密度一定シナリオでも鉄軌道の選定地域までに は至らずBRT選定地域となる。 また, 都市域縮退によっ て乗合輸送機関の $\mathrm{CO}_{2}$ 削減効果が高まるため, 総導入延 長は減少する.

このことから，都市域縮退施策と乗合輸送機関の組み 合わせによって乗合輸送機関の $\mathrm{CO}_{2}$ 削減効果が高められ， 
表-9 都市域縮退による SyLC-CO 2 最小輸送機関選定地域の変化(2050年)

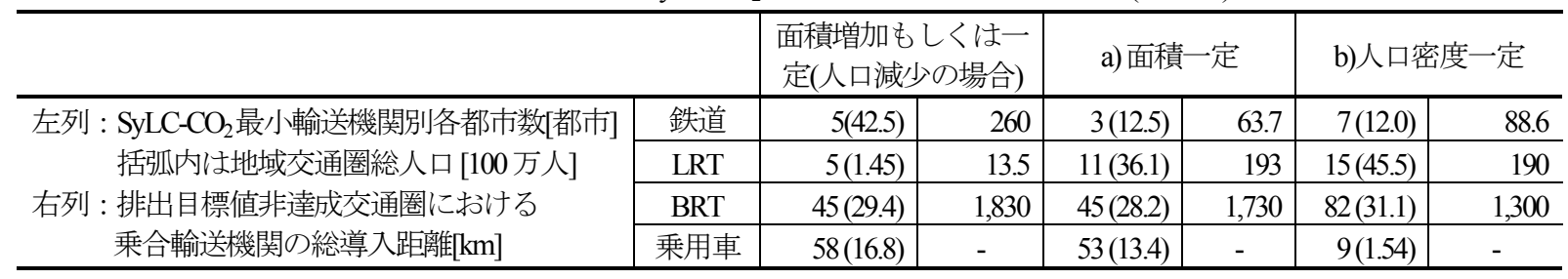

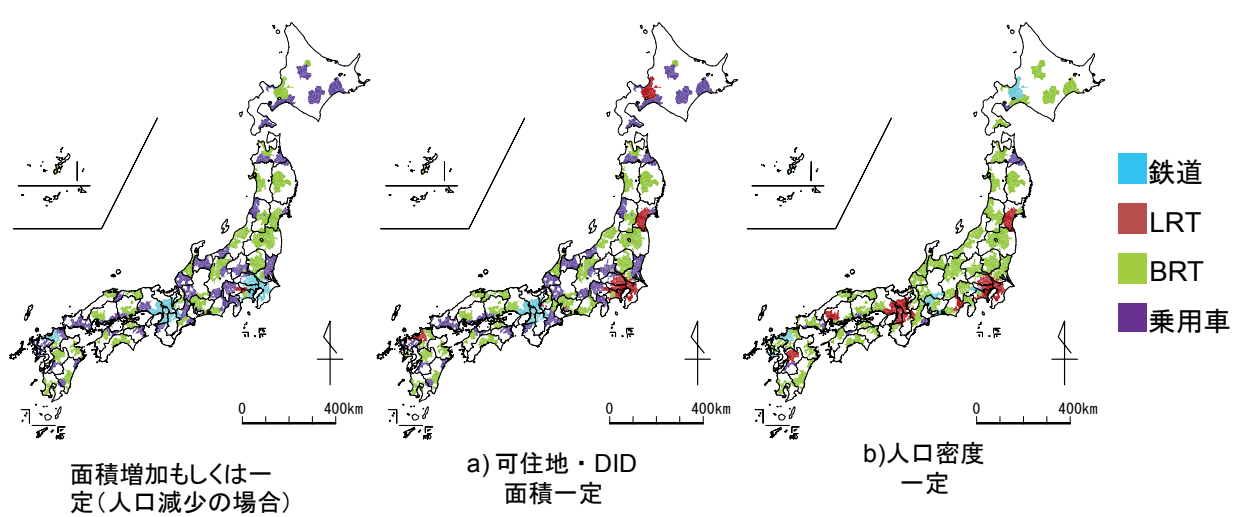

図-9 各地域交通圈の SyLC-CO $\mathrm{C}_{2}$ 最小輸送機関選定結果

特にBRTの導入が有効となる地域が大幅に増加するとき に，必要整備量も減らすことができることが確かめられ た.

\section{5. 結論}

本研究では，日本の2050年における地域内旅客交通起 源 $\mathrm{CO}_{2}$ 排出量の 2000 年比 $80 \%$ 削減を目標に据え，その達 成のために，地域交通圏別に導入すべき乗合輸送機関の 選択方法と必要整備量の決定手法を構築し，算出を行っ た. 得られた主な成果を以下に示す.

- 人口減少と車両・燃料技術向上によって，日本全体 の $\mathrm{CO}_{2}$ 排出量は2000年比で66\%削減される。ただし, ほとんどの地域交通圈で $80 \%$ 削減は達成できない.

- 車両 - 燃費技術改善や乗合輸送機関の輸送密度の低 下に伴い，2050年においてSyLC-CO 2 最小となる輸送 機関が乗用車となる(つまり，乗合輸送機関の導入 によって $\mathrm{CO}_{2}$ が削減されない)地域交通圈が多数生じ ることが把握された。

- 鉄道整備によって $\mathrm{CO}_{2}$ 削減を行う場合，東京・京阪 神では100kmを超える路線整備が必要となること， 地方都市でも数十 $\mathrm{km}$ 単位での整備が必要となるこ とが分かった。

・ 都市域縮退によって人口密度を高めることで乗合輸 送機関の $\mathrm{CO}_{2}$ 削減効果が高まり, 選定地域の増加, 必要整備量の減少が確認できた.

今後は，以下の分析追加が必要であると考えている.
- 地域交通圈に属さない非都市部における自家用乗用 車保有率のモデル化を行っていない，この地域で人 口構成割合の高い高齢者について，自動車保有率が 今後上昇することが予想され，そのモデル化が必要 である。

・ 乗合輸送機関の導入による $\mathrm{CO}_{2}$ 排出量の削減効果は, 整備の進展に伴い適地が減るため，莪減すると考え られるが，本研究では考慮できていない，また，乗 合輸送機関導入以外の交通施策についても検討を加 えるべきである.

・ 乗合輸送機関の導入，都市域縮退といった施策につ いて費用を計算し，費用対効果を評価することが必 要である.

・ 本研究では，乗合輸送機関導入によって乗用車から 利用者が転換するとしているが，その転換量の大小 に影響を与える運覒・鉄道サービス水準を分析指標 として追加することが必要である.

謝辞 : 本研究は, 環境省・環境研究総合推進費(S-6-5)

「アジアにおける低炭素交通システム実現方策に関する 研究」の支援により実施された。ここに記して謝意を表 する.

\section{参考文献}

1) IPCC : 第 4 次評価報告書第 2 作業部会報告書, 2007 .

2) 環境省：地球温暖化対策に係る中長期ロードマップ の提案～環境大臣 小沢鋭仁 試案〜, http://www.env. go.jp/earth/ondanka/domestic.html, 2010.

3) 大口敬，片倉正彦，谷口正明：都市部道路交通にお ける自動車の二酸化炭素排出量推定モデル，土木学 
会論文集，No.694，pp.125-136，2002.

4) 大城温, 松下雅行, 並河良治, 大西博文 : 自動車走 行時の燃料消費率と二酸化炭素排出係数，土木技術 資料, Vol.43, No.11，pp.50-55， 2001.

5) 平野全宏, 中道久美子, 谷口守, 松中亮治: 都市別 自動車 $\mathrm{CO}_{2}$ 排出量の定量化とその経年変化分析, 環 境システム研究論文集，Vol.36，pp.19-25，2008.

6) 松橋啓介, 工藤祐揮，上岡直見，森口祐一：市区町 村の運輸部門 $\mathrm{CO}_{2}$ 排出量の推計手法に関する比較研 究, 環境システム研究論文集, Vol.32, pp.235-242, 2004.

7) 工藤祐揮, 松橋啓介, 上岡直見, 森口祐一：市区町 村の運輸部門 $\mathrm{CO}_{2}$ 排出量の推計, 第 33 回環境システ 么研究論文発表会講演集，北海道，pp.263-268，2005.

8) 小島浩, 吉田朗, 森田哲夫 : 交通・環境負荷を小さ くする都市構造と交通施策に関する研究, 都市計画 論文集，Vol.38，No.3，pp.553-558，2003.

9) 山崎清, 上田孝行, 岩上一騎 : 交通インフラ整備の 都市構造及び持続可能性へ与える影響分析, 土木計 画学研究・講演集, Vol.39, CD-ROM, 2009.

10) 中村英樹, 林良嗣, 都築啓輔, 加藤博和, 丸田浩 史：目標設定型アプローチによる運輸起源の $\mathrm{CO}_{2}$ 排 出削減施策の提示, 土木計画学研究・論文集, Vol.15, pp.739-746, 1998.

11) 栗山和之, 崔東海, 加藤博和, 林良嗣：日本の環境 配慮型交通施策導入プロセスにおける問題点の検討, 第 11 回地球環境シンポジウム講演論文集, 大宮, pp.259-264, 2003.

12) 郷智哉, 加藤博和, 谷田一: 脱温暖化社会を目指し
た地域類型別交通施策パッケージ提案手法，土木計 画学研究・講演集, Vol.36, CD-ROM, 2007.

13) Kawashima, T., Hiraoka, N., Okabe, A. and Ohtera, N.: Metropolitan Analysis : Boundary Delineations and Future Population Changes of Functional Urban Regions, Gakushuin Economic Papers, Vol.29, pp.205-248, 1993.

14）環境省：地球温暖化対策の推進に関する法律施行令 で定める排出係数一覧, 温室効果ガス排出量の算定 に用いる排出係数について，2006.

15）エネルギー総合工学研究所 : 超長期エネルギー技術 ロードマップ報告書, エネルギー総合工学研究所 : 研究成果, http://www.iae.or.jp/research/result/cho06. html, 2006.

16) トヨタ自動車 : 環境報告書 2002，2002.

17) 三菱自動車 : テクニカルレビュー2008, 2008.

18）近藤稔：モーターの効率を上げる, 技術情報誌, Vol.66, No.3, pp.10-13, 2009.

19）長田基広, 渡辺由紀子, 柴原尚希, 加藤博和：LCA を適用した中量旅客輸送機関の環境負荷評価, 土木 計画学研究・論文集, Vol.23, No.2, pp.355-363, 2006.

20) Kudoh, Y., Yagita, H. and Inaba, A.: Analysis of Existing Variation in Fuel Consumption of Hybrid Electric Vehicles, Electric Proceedings of International Conference on Ecologic Vehicles \& Renewable Energies, 2007.

(2011.2.25 受付)

\section{ESTIMATING THE PROVISION LENGTH OF MINIMUM LC-CO $\mathrm{MODE}^{\mathrm{M}}$ IN TRUNK LINES FOR LARGE REDUCTION OF $\mathrm{CO}_{2}$ EMISSION FROM REGIONAL PASSENGER TRANSPORT IN JAPAN}

\section{Kei ITO, Hirokazu KATO and Naoki SHIBAHARA}

This study aims to estimate the required level of mass transit development in trunk lines to achieve the target of $\mathrm{CO}_{2}$ emissions from intra-regional passenger transport.

The target of $\mathrm{CO}_{2}$ emission from intra-regional passenger transport in 2050 is set $20 \%$ of that in 2000 in each region. First, the spread of innovative technologies is forecasted and then $\mathrm{CO}_{2}$ reduction from it is estimated. The remaining amount of the targeted reduction is identified as the required reduction from transport policies. The change in $\mathrm{CO}_{2}$ emission resulting mass transit development is estimated, including the reduction from replacing private vehicles and the emissions arising from construction and operation of the transit system. For this purpose, the methodology of Life Cycle Assessment is applied. The transit system that emits the least $\mathrm{CO}_{2}$ per passenger-km is identified for each region.

Accordingly, the results of this analysis show the necessary lengths of additional mass transit lines depending on urban area and population density, in order to achieve the $\mathrm{CO}_{2}$ reduction target for intraregional passenger transport by 2050 . 